Article

\title{
The Performance and Potentiality of Monoecious Hemp (Cannabis sativa L.) Cultivars as a Multipurpose Crop
}

\author{
Mario Baldini ${ }^{1, *} \mathbb{1}$, Claudio Ferfuia ${ }^{1}$, Barbara Piani ${ }^{1}$, Angela Sepulcri ${ }^{1}$, Gaia Dorigo ${ }^{1}$, \\ Fabio Zuliani ${ }^{1}$, Francesco Danuso ${ }^{1}$ and Costantino Cattivello ${ }^{2}$ \\ 1 Department of Agricultural, Food, Environmental and Animal Sciences (DI4A) University of Udine, \\ Via delle Scienze, 206, 33100 Udine, Italy; claudio.ferfuia@uniud.it (C.F.); barbara.piani@uniud.it (B.P.); \\ angela.sepulcri@uniud.it (A.S.); dorigo.gaia@spes.uniud.it (G.D.); fabio.zuliani@uniud.it (F.Z.); \\ francesco.danuso@uniud.it (F.D.) \\ 2 ERSA FVG-Substrates Laboratory, Via Sabbatini, 5, 33050 Pozzuolo del Friuli (UD), Italy; \\ costantino.cattivello@ersa.fvg.it \\ * Correspondence: mario.baldini@uniud.it; Tel.: +39-0432-558663
}

Received: 11 July 2018; Accepted: 22 August 2018; Published: 24 August 2018

\begin{abstract}
Given the growing interest in multipurpose hemp crop, eight monoecious cultivars were compared in a two-year trial for quantitative and qualitative yield in a Mediterranean environment characterized by a temperate and humid climate with hot summers. All hemp cultivars were evaluated for yield potential of (i) seed plus stem at seed maturity, and (ii) essential oil yield from inflorescences harvested at full flowering. The second goal was set to test the ability of cultivars to supply new seeds after the removal of inflorescence at full flowering. Among the cultivars, Fedora obtained the best results for seed $\left(0.79\right.$ and $\left.0.52 \mathrm{t} \mathrm{ha}^{-1}\right)$ and vegetable oil yield $\left(0.17\right.$ and $\left.0.09 \mathrm{tha}^{-1}\right)$ normally and with inflorescence removed plants, respectively. Futura, conversely, showed the best results for inflorescence $\left(3.0 \mathrm{t} \mathrm{ha}^{-1}\right)$, essential oil $\left(9 \mathrm{~L} \mathrm{ha}^{-1}\right)$, and stem yield at seed maturity $\left(8.34 \mathrm{tha}^{-1}\right)$, as means across the two years. The cultivars studied generally reached the grain-filling stage during a period that was drier and warmer than the average of the same multi-year period, and this negatively affected seed quality. The oil fatty acid composition was mainly composed of polyunsaturated fatty acids ( $75 \%$ on average) and not affected by the cultivar. In conclusion, although the hemp grower should always clearly know the main production objective of the crop, the monoecious cultivars available today allow a multipurpose use of hemp crop, improving the sustainability of the cultivation activity.
\end{abstract}

Keywords: Cannabis sativa; multipurpose hemp; essential oil; seed oil

\section{Introduction}

Traditionally, in central and southern Europe, breeding aspects and agronomic techniques of hemp cultivation have always been designed for textiles and clothing production. During the 20th century, due to competition from other feedstocks such as cotton and synthetic fibers, which were more economical, hemp cultivation declined progressively. An exception to this trend was found in France, where the consolidated market in hemp pulp and paper, supplied mainly by French producers, allowed a certain constancy of acreage [1]. Today, the products obtained from hemp cultivation can be used in numerous agro-industrial fields such as agriculture, textiles, bio-composites, papermaking, construction, biofuel, functional foods, personal care, and cosmetics [2,3]. This multipurpose production has led to renewed interest in industrial hemp. However, few studies have compared the performances of the current commercial genotypes of industrial hemp [4] for the combination of 
fiber and seeds, a practice that is now popular in many European countries [5]. Recently, the area of hemp cultivated in Europe has increased from 15,700 hectares in 2013 to 33,000 in 2016, with a further increase expected, mainly driven by the growing demand for hemp seed by the food market [6]. Seed yield increased from 6000 to 11,500 tons from 2010 to 2013 (92\% growth) mainly for edible oil and flour production [7]. In addition, new applications for hemp fibers were developed in the 1990s, such as biocomposites (about $15 \%$ of the total hemp fiber produced in the EU is used for automobile biocomposites), insulation materials, and other non-woven applications requiring short nonaligned technical fibers, now virtually the only type obtained from the processing of hemp straw in Europe. Today the cultivation of multipurpose cultivars, with joint production of seeds and fiber, is a minimum requirement for hemp farmers and this has opened new challenges in many research sectors such as breeding [3,4]. In Europe, the number of registered industrial hemp cultivars has risen rapidly from 12 in 1995 to 57 in 2016, most of them monoecious, considered particularly suitable for this type of use, as they allow greater uniformity, easier mechanical harvesting, and higher seed yield $[2,8]$. Furthermore, interest has recently been growing in the utilization of hemp inflorescences for extracting essential oils [9], namely non-psychotropic cannabinoids, terpenoids, and flavonoids [10] from the low-THC types cultivated. These provide interesting uses for cosmetic and medical applications, food supplements, and in agriculture, having activity against microbes [11,12], nematodes [13], mesophilic fungi [14], and insects [15-18]. This utilization, which involves harvesting inflorescences at flowering time, seems to exclude the production of seed, limiting the full exploitation of the crop. Since hemp is very sensitive to environmental conditions such as day-length and temperature and considering that cultivars are typically developed for specific environments and cropping conditions, it is important to extend the evaluation of available cultivars in different years $[4,19]$. The main aims of this experiment were to study the performance of some monoecious hemp cultivars to evaluate their quantitative and qualitative yield of seed, inflorescence, and stems at seed harvest time through a two-year experiment in a Mediterranean environment. Moreover, with the aim of using the inflorescences for essential oils yield, the ability to supply new seeds by the same plant after the harvest of inflorescences at full flowering was evaluated.

\section{Materials and Methods}

\subsection{Plant Material}

Eight cultivars of different origin were used in this experiment and their main characteristics are reported in Table 1. The cultivars studied were monoecious (with both female and male flowers on the same inflorescence), considered suitable for seed and/or dual-purpose (seed and fiber) and differed in earliness as well as origin.

Table 1. Main characteristics of the eight monoecious cultivars utilized in the trial.

\begin{tabular}{ccc}
\hline Cultivar & Origin & Maturity Group \\
\hline Jubileu & Romania & Very Early \\
Uso-31 & Ukraine & Early \\
KC Zuzana & Hungary & Early \\
Fedora 17 & France & Medium-Early \\
Fibrol & Hungary & Medium \\
Monoica & Hungary & Medium \\
KC Dora & Hungary & Late \\
Futura 75 & France & Late \\
\hline
\end{tabular}

\subsection{Site and Field Experiment Description}

The field experiment was conducted in 2016 and 2017 at the Experimental Farm of Udine University, Udine, Italy ( $46^{\circ} 4^{\prime} \mathrm{N}, 13^{\circ} 22^{\prime} \mathrm{E}$, height $109 \mathrm{~m}$ above sea level and $0 \%$ slope). The site has shallow soil 
(about $50 \mathrm{~cm}$ ) with a loamy-sandy texture (average sand, silt, and clay, 40, 43, and 17\%, respectively), a $\mathrm{pH} 7.3$, and a moderate continental climate with wet connotation, the main traits of which are reported in Table 2.

Table 2. Monthly mean maximum temperature (Tmax), minimum temperature (Tmin), and total rainfall during the growing seasons at Udine (Italy) in 2016 and 2017, as well as the 25-year mean (1992-2016) at Udine.

\begin{tabular}{|c|c|c|c|c|c|c|c|c|c|}
\hline \multirow[b]{2}{*}{ Month } & \multicolumn{3}{|c|}{2016} & \multicolumn{3}{|c|}{2017} & \multicolumn{3}{|c|}{ 1992-2016 Average } \\
\hline & $\operatorname{Tm} \min \left({ }^{\circ} \mathrm{C}\right)$ & $\operatorname{Tmax}\left({ }^{\circ} \mathrm{C}\right)$ & $\begin{array}{c}\text { Rainfall } \\
(\mathrm{mm})\end{array}$ & $\operatorname{Tmin}\left({ }^{\circ} \mathrm{C}\right)$ & $\operatorname{Tmax}\left({ }^{\circ} \mathrm{C}\right)$ & $\begin{array}{c}\text { Rainfall } \\
(\mathrm{mm})\end{array}$ & $\operatorname{Tmin}\left({ }^{\circ} \mathrm{C}\right)$ & $\operatorname{Tmax}\left({ }^{\circ} \mathrm{C}\right)$ & $\begin{array}{c}\text { Rainfall } \\
(\mathrm{mm})\end{array}$ \\
\hline May & 11.1 & 22.3 & 238.3 & 11.8 & 24.2 & 80.6 & 12.2 & 23.4 & 122.6 \\
\hline June & 15.9 & 26.5 & 122.4 & 16.2 & 29.3 & 163.6 & 15.5 & 26.9 & 124.9 \\
\hline July & 17.7 & 30.6 & 92.3 & 17.4 & 30.3 & 61.8 & 17.0 & 29.4 & 117.7 \\
\hline October & 8.2 & 18.4 & 123.8 & 7.2 & 19.8 & 38.2 & 9.0 & 19.0 & 167.8 \\
\hline Mean & 13.0 & 24.8 & & 12.8 & 25.2 & & 12.9 & 24.4 & \\
\hline Total & & & 825.7 & & & 882.76 & & & 948.6 \\
\hline
\end{tabular}

The previous crops were wheat in 2016 and oat in 2017; the soil was plowed to a depth of $30 \mathrm{~cm}$ in autumn and then maintained free of weeds by means of disc harrow cultivation whenever necessary.

Two weeks before hemp sowing, the soil was disked twice for seedbed preparation. The sowing occurred on April 20 in both years, using a plot seeder (Wintersteiger AG, Ried im Innkreis, Austria) in rows at $0.15 \mathrm{~m}$ interrow spacing, using about 130 viable seeds per $\mathrm{m}^{2}$, with an average sowing depth of $3 \mathrm{~cm}$.

Fertilization consisted of $20 \mathrm{~kg} \mathrm{P} \mathrm{ha}^{-1}$ incorporated prior to seeding and $80 \mathrm{~kg} \mathrm{~N}^{-1}$, as urea, about 20 days after crop emergence. A supplemental irrigation of $30 \mathrm{~mm}$ during a drought period in early July was applied in 2016. In 2017, due to very low rainfall, two irrigations of $30 \mathrm{~mm}$ each, spaced apart by 20 days, were applied in July and the beginning of August.

\subsection{Plot Structure and Sampling Scheme}

The experimental scheme adopted was a randomized block design with four replications, with each experimental unit being $25 \mathrm{~m}^{2}$. For each plot, the following sampling scheme was adopted:

(1) A $1.0 \mathrm{~m}^{2}$ area was randomly selected in each unit. This was identified immediately after sowing, and the number of plantlets until full emergence and at harvest were counted. The emergence date for each genotype was set when $75 \%$ of seedlings had emerged.

(2) Fifteen representative plants were randomly selected in the $25 \mathrm{~m}^{2}$ plot to determine phenological stages [20] by twice-weekly surveys.

(3) An area of $1.8 \mathrm{~m}^{2}$ for each experimental unit, discarding the border rows, was utilized to collect the inflorescences at the full flowering stage [20]. The fresh inflorescences were collected after manually cutting the upper part of the plant stem at the insertion level of the first basal flowers of the inflorescence. The fresh inflorescences were directly utilized to obtain the essential oil by distillation. The same plants, after the development of new inflorescences, were harvested at maturity to measure seed yield.

(4) A $4 \mathrm{~m}^{2}$ area, discarding the border rows, was harvested to obtain the crop yield, both as biomass (fiber) and seeds. Plants were cut manually, at $10 \mathrm{~cm}$ from the soil surface. Plant height was measured from the base to the top of the inflorescence. Harvesting was performed at the seed maturity stage [20]. 


\subsection{Determination of Biomass, Seed and Seed Oil Yield}

In order to evaluate the total aboveground and stems biomass, harvested plant material was oven-dried at $60{ }^{\circ} \mathrm{C}$ until constant weight. Seeds, separated from the inflorescence by means of a threshing machine, were cleaned, the empty seeds were removed, and the remainder was weighed for seed yield determination. A representative sub-sample of dried seed from each unit was finely grinded, stored at $4{ }^{\circ} \mathrm{C}$, and used for further analysis.

Ether extracts (EE) were obtained according to the Soxhlet method, extracting the seed with petroleum ether (boiling point $40{ }^{\circ} \mathrm{C}-60^{\circ} \mathrm{C}$ ) using a Soxhlet apparatus. The petroleum ether was then removed by evaporation under nitrogen gas flow and the oil was dried over anhydrous sodium sulfate $\left(\mathrm{Na}_{2} \mathrm{SO}_{4}\right)$ and quantified. To obtain the fatty acid composition, an aliquot of oil was dissolved in $1 \mathrm{~mL}$ of $n$-hexane. Fatty acids were converted into fatty acid methyl esters (FAMEs) by transesterification with a methanolic potassium hydroxide solution (2N) and then vortexed for $30 \mathrm{~s}$. Composition was determined by gas chromatography with flame ionization detection (GC-FID, Fisons Instrument Mega 2 series, Rodano, Milan, Italy) and each fatty acid was expressed as a percentage of the total detected in the oil. The gas chromatograph was fitted with a 60-m HP-88 capillary column (Agilent Technologies, Santa Clara, CA, USA). Helium was used as carrier gas $\left(2 \mathrm{~mL} \mathrm{~min}^{-1}\right.$ constant flow), and the injector, detector, and oven temperatures were 230,250 , and $200^{\circ} \mathrm{C}$, respectively. Five microliters of sample were injected in split mode and the split ratio was 1:100. A 5.0-mm internal diameter precision inlet split liner was used. Different FAMEs were identified by comparison with known standards.

The seed oil fatty acids profile was determined only in the first year of the trial.

\subsection{Inflorescence Yield and Essential Oil Content Determination}

Fresh inflorescences were split, a portion was weighted and then subjected to ventilated oven-drying at $50{ }^{\circ} \mathrm{C}$ until constant weight, and the rest of the fresh inflorescences were immediately stored in plastic bags in the dark at $-20^{\circ} \mathrm{C}$ for further essential oils extraction. The frozen fresh inflorescences were defrosted at room temperature, then submitted to essential oil extraction by hydrodistillation, through a Clevenger-type apparatus described in the Italian Pharmacopoeia (F.U.I. XII Ed.). Briefly, $100 \mathrm{~g}$ of fresh inflorescence was chopped and placed in round bottom flask, to which $600 \mathrm{~mL}$ of distilled water was added. The flask was connected to a condenser and the flow was adjusted to $2 \mathrm{~mL} \mathrm{~min}^{-1}$ of condensate. Distillation was continued for $3 \mathrm{~h}$. Yield in essential oil was expressed as $\mathrm{v} / \mathrm{w}$ (mL of oil /100 $\mathrm{g}$ of dry plant material).

\subsection{Statistical Analysis}

All traits were subjected to two-way analysis of variance (ANOVA) with "year" (Y) and "cultivar" (C) as the main effects, using a fixed-model. When ANOVA revealed significant differences between means, a Student-Newman-Keuls test at $p \leq 0.05$ was used to separate means. The term 'significant' is only used for traits showing statistical significance.

\section{Results and Discussion}

\subsection{Climate during the Experimentation}

Table 2 reports the air temperature and precipitation recorded during the hemp crop cycle in 2016 and 2017, compared to the previous 25-year period (1992-2016). Total precipitation during the period of April-October was 826 and $883 \mathrm{~mm}$ in 2016 and 2017, respectively, lower than the multi-year mean for the same period $(949 \mathrm{~mm}$ ). Minimum and maximum average temperatures in the previous 25-year period were 12.9 and $24.4^{\circ} \mathrm{C}$, respectively, similar to these of both years of experimentation. However, in analyzing the period of July-August, when flowering and grain-filling of the hemp cultivars studied occurred in this environment, differences were apparent. In fact, during the July-August period, the rainfall was significantly lower than the previous 25 -year period (64\% in 2016 and $44 \%$ in 2017). Considering the same two summer months, the maximum average temperatures were 
significantly higher (about $0.5^{\circ} \mathrm{C}$ in 2016 and $1.4{ }^{\circ} \mathrm{C}$ in 2017) than the same average of the previous 25 years. In particular, August 2017 reached a maximum average temperature higher by $1.8^{\circ} \mathrm{C}$ than the multi-year period, which ranged from 25.9 to $34.4^{\circ} \mathrm{C}$, with a standard deviation of $2.1^{\circ} \mathrm{C}$. The total rainfall of August 2017 was $47 \mathrm{~mm}$, while the multi-annual values ranged from 23 to $321 \mathrm{~mm}$, with a standard deviation of $77 \mathrm{~mm}$ and an average of $127 \mathrm{~mm}$.

\subsection{Phenology and Biometric Characteristics}

Emergence (when $75 \%$ of the hemp seedlings had emerged) occurred uniformly for all cultivars and replications, about 9 and 12 days after sowing in 2016 and 2017, respectively. Flowering time, averaged over cultivars, occurred around mid-July in both years, yet highlighting a wide difference between cultivars, which is in agreement with other experiments [21]. The cultivar Uso-31, selected in the Ukraine, and the Romanian cultivar Jubileu were the first to flower (end June-early July), confirming their earliness with a very similar emergence-flowering duration (60-65 days) in both years (Figure 1). On the contrary, the other cultivars started to flower during late July-August in both years, delaying the flowering in 2017 when compared to 2016, with the exception of Fedora and Zuzana. The fact that flowering was delayed in some cultivars while others exhibited the same phenological development in 2017 with respect to 2016 make results difficult to explain. Probably this is due to the complex interactions among climatic conditions, cultivars, and irrigation that, applied at the beginning of August 2017, corresponded to the incipient flowering of late varieties only. In addition, the flowering time of hemp can vary greatly with the latitude of cultivation [21,22]. Hemp growth is affected by day length and relies on the interaction between growing degree and day accumulation to switch from the vegetative to the reproductive phase. Furthermore, a cultivar is cultivated at a lower latitude, it will generally flower earlier. To avoid a rapid genetic shift towards a different phenological pattern, sowing-seed production has to take place at the appropriate latitude [23-25]. The flower-maturity period was not influenced by the cultivar $\times$ year $(C \times Y)$ interaction, but only by the effect of the year. In particular, this phase, on average across cultivars, was about 10 days longer in 2017 than in 2016, with the earliest cultivars exhibiting a significantly increased flower-maturity period.

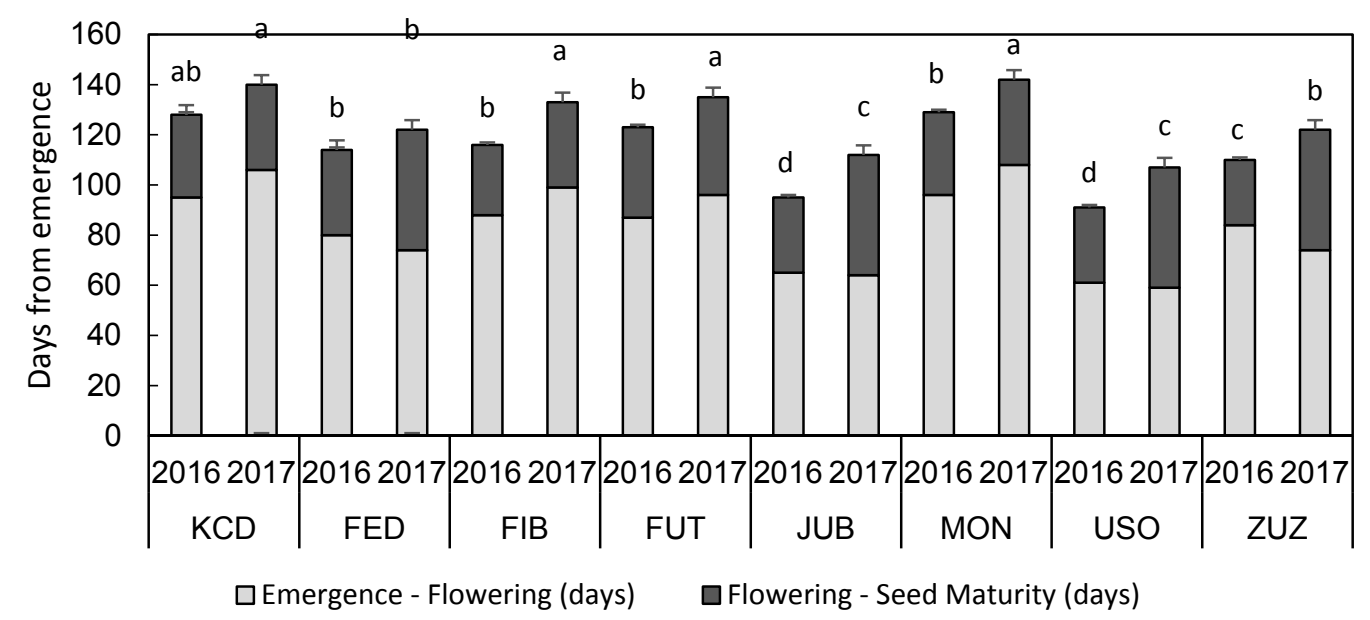

Figure 1. Main growth stages duration of hemp cultivars studied (KCD = KC Dora; FED = Fedora 17; FIB = Fibrol; FUT = Futura 75; JUB = Jubileu; MON = Monoica; USO = Uso-31; ZUZ = Zuzana). Means followed by the same letter are not significantly different (SNK at the 5\% level). Error bars, as standard deviations, referred to the emergence-seed maturity period.

As is well known, the flowering-maturation period is generally poorly affected by specific genotype characteristics, but much more by the environmental conditions $[4,26]$. Monoecious cultivar plants usually have both male and female flowers in the same inflorescence, with a high dominance of the latter. All cultivars of Hungarian origin, although registered as monoecious, presented a significant 
presence of male plants (about 40\% in Zuzana, Fibrol, and Monoica and 30\% in Dora in 2016, as well as 39\% in Zuzana, 27\%-28\% in Monoica and Dora, and 11\% in Fibrol in 2017) (Figure 2). These values were very high compared to the other monoecious cultivars, in which the presence of male-only plants did not exceed $6 \%$ (Figure 1). The phenotypic expression of gender in hemp has been reported by several authors to be subject to environmental and hormonal influences and it is generally accepted that monoecious plants can express their genetic potential to form both types of flowers on the same plant, depending on environmental conditions [8]. Nevertheless, there is a possible environmental effect in influencing the ratio of male to female flowers in monoecious plants. In this case, given the high percentages of full-male plants and because it only occurred in all cultivars coming from a single research center, it may be due to an inadequate and insufficient selection and stability of the basic genetic material utilized for seed reproduction.

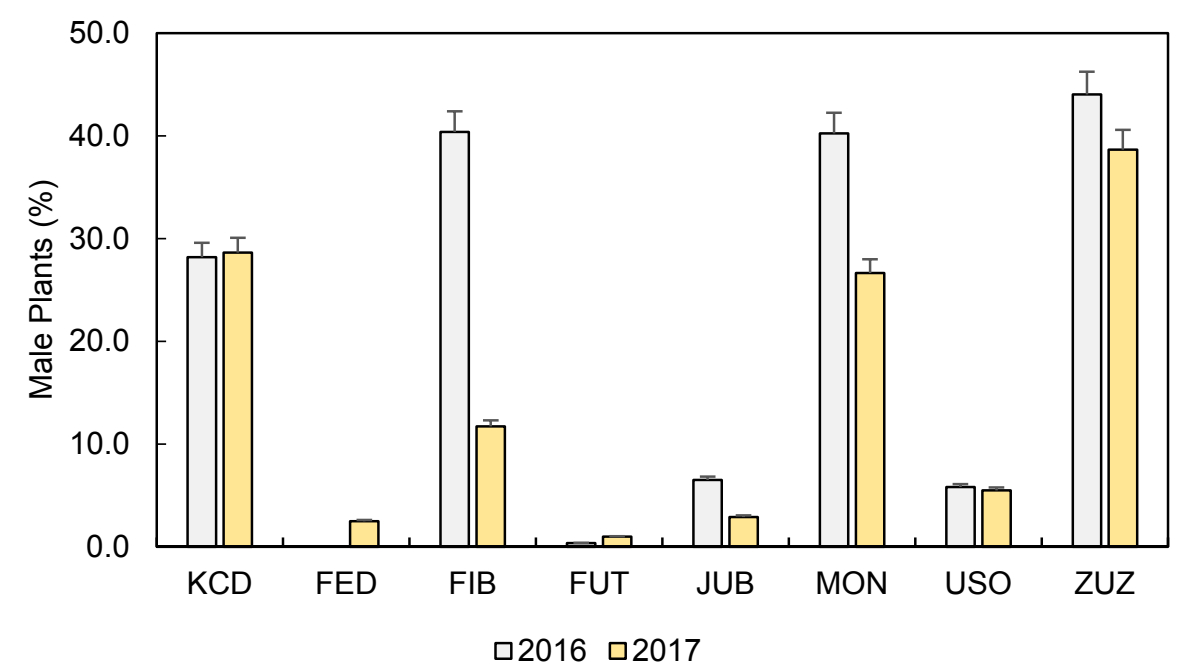

Figure 2. Presence of male plants. Data are means, error bars are standard deviations. $(\mathrm{KCD}=\mathrm{KC}$ Dora; FED = Fedora 17; FIB = Fibrol; FUT = Futura 75; JUB = Jubileu; MON = Monoica; USO = Uso-31; $\mathrm{ZUZ}=$ Zuzana).

Table 3 summarizes the results of ANOVA on different crop traits.

Table 3. Summary of ANOVA results on crop traits as a function of year and cultivar of control plants.

\begin{tabular}{|c|c|c|c|c|c|c|c|c|}
\hline \multirow{2}{*}{ Source } & \multirow{2}{*}{$\begin{array}{l}\text { Plant } \\
\text { Height }\end{array}$} & \multirow{2}{*}{$\begin{array}{l}\text { Male Plants } \\
\text { Percentage }\end{array}$} & \multirow{2}{*}{$\begin{array}{c}\text { Inflorescence } \\
\text { Height }\end{array}$} & \multirow{2}{*}{$\begin{array}{l}\text { Stem } \\
\text { Yield }\end{array}$} & \multirow{2}{*}{ Oil Yield } & \multicolumn{3}{|c|}{ Seed } \\
\hline & & & & & & Yield & SW $^{\mathrm{a}}$ & Oil Content \\
\hline Year $(Y)$ & $* * *$ & $* *$ & ns & $* *$ & * & $* * *$ & ns & $* * *$ \\
\hline $\begin{array}{l}\text { Cultivar } \\
\text { (C) }\end{array}$ & $* * *$ & $* * *$ & ns & $* * *$ & $* * *$ & $* * *$ & $* * *$ & $* * *$ \\
\hline$C \times Y$ & ns & * & ns & ns & ns & ns & * & $* * *$ \\
\hline
\end{tabular}

The average plant density at plant emergence was 78 and 90 plants $\mathrm{m}^{-2}$ in 2016 and 2017, respectively, with a maximum shift from the above averages of -18 and $+16 \%$ in the first and second year, respectively. These plant densities are considered suitable for crops destined mainly for seed production [4]. The maximum plant height was influenced by cultivar $(\mathrm{C})$ and year $(\mathrm{Y})$, but not by their interaction $(C \times Y)$. The average plant height across cultivars was $225 \mathrm{~cm}$ in 2016, a significantly higher value than that obtained in $2017(190 \mathrm{~cm})$. Among the cultivars across the two years, the shortest was Jubileu $(134 \mathrm{~cm})$, while Monoica reached the maximum value $(237 \mathrm{~cm})$ (Figure 3). These differences in plant height were determined essentially by the differences in stem height, because no significant 
statistical differences were found for the length of inflorescences $(19.4 \mathrm{~cm}$, mean of years and cultivars), which corresponded to about $9.3 \%$ of the plant height as a mean (Figure 3).

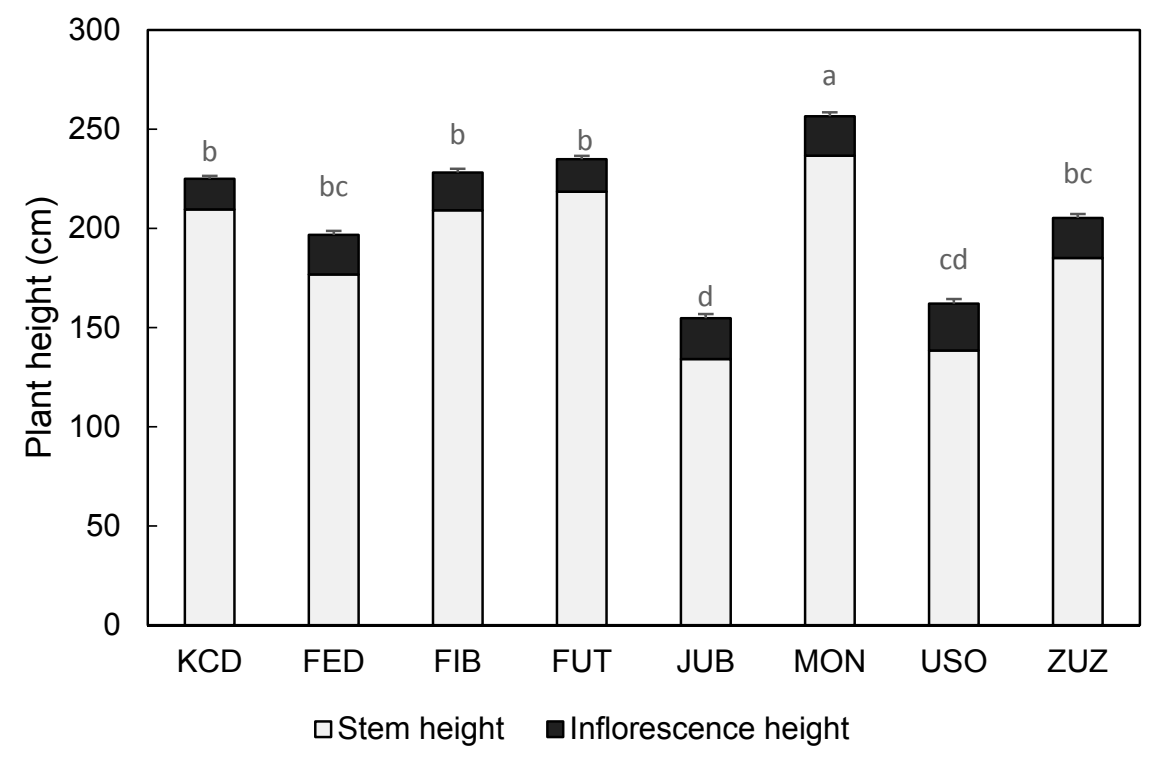

Figure 3. Maximum plant height of the cultivar studied $(\mathrm{KCD}=\mathrm{KC}$ Dora; FED = Fedora 17; FIB = Fibrol; FUT = Futura 75; JUB = Jubileu; MON = Monoica; USO = Uso-31; ZUZ = Zuzana). Means followed by the same letter are not significantly different (SNK at the $5 \%$ level). Error bars are standard deviations.

\subsection{Main Seed Characteristics}

At full flowering, inflorescences were harvested in order to study the potential of essential oils yield. After that, the plants deprived of the main inflorescence reacted by issuing new inflorescences in a variable number (2-4 per plant) from dormant buds situated on the main stem below the cut line. The new inflorescences started to flower after a re-growth period of 7-10 days. Consequently, we investigated the seed yield and quality of the intact plants (controls in the text) in comparison with the same traits obtained from the plants with inflorescences harvested at flowering time (plants with inflorescence removed in the text).

Both the seed weight of the control plants and of plants with inflorescences harvested at flowering were affected significantly by the cultivar $\times$ year interaction. The average seed weight of the controls across cultivars was very similar for both years (7.7 and $7.5 \mathrm{~g}$ for 1000 seeds in 2016 and 2017, respectively) (Figure 4), although Jubileu had significantly reduced seed weight by about $25 \%$ in 2017 compared to 2016. The range in cultivar values obtained in this experiment (5.7-9.8 g) was lower than that obtained by several other authors $[7,22,27]$. The seed weight of plants with inflorescence removed, averaged over cultivars, was statistically higher $(7.5 \mathrm{~g})$ in 2017 than that in 2016 (6.2 g). The same seed weight remained unchanged with respect to the values of the controls in 2017 and decreased by about $20 \%$ in 2016. With regard to the cultivars, all showed a significant increase in the seed weight in 2017 compared to 2016, with the exception of the two earliest cultivars, Jubileu and Uso-31, which had reduced seed weight in the second year. 

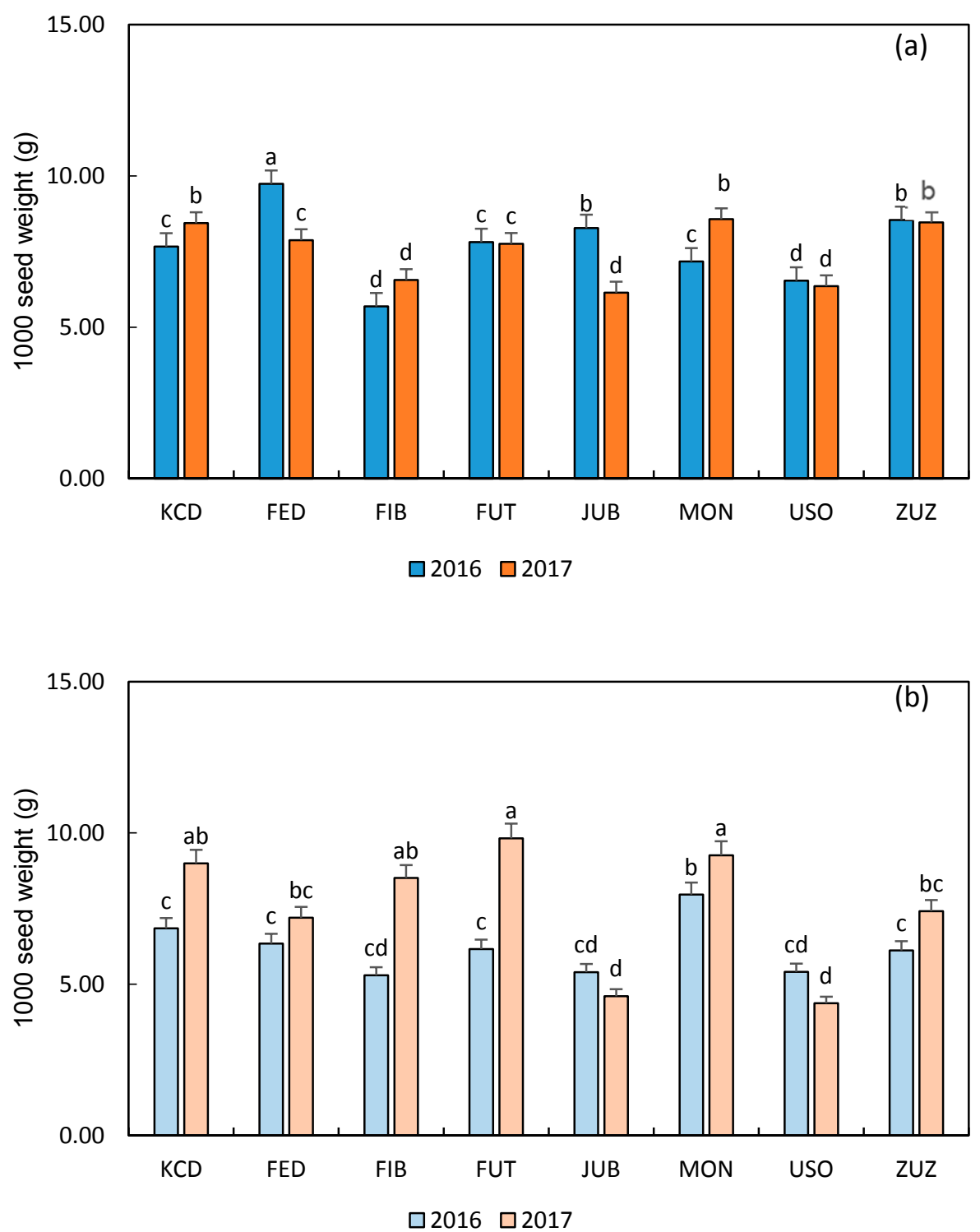

Figure 4. One thousand seed weight in control plants (a) and in plants with inflorescence harvested at flowering (b) $(\mathrm{KCD}=\mathrm{KC}$ Dora; FED = Fedora 17; FIB = Fibrol; FUT = Futura 75; JUB = Jubileu; MON = Monoica; USO = Uso-31; ZUZ = Zuzana). Means followed by the same letter are not significantly different (SNK at the 5\% level). Error bars are standard deviations.

The $\mathrm{C} \times \mathrm{Y}$ interaction influenced seed oil content; on the contrary, the same characteristic in inflorescence-removed plants was influenced by year $(\mathrm{Y})$ and cultivar $(\mathrm{C})$, but not by the interaction between them $(C \times Y)$. In 2017, the average seed oil contents were higher (control seeds $23.0 \%$ and seeds after regrowth 20.2\%) compared to 2016 (18.1 and 15.7\%, in controls and in plants with inflorescence removed, respectively). In particular, only the two earliest cultivars, Uso-31 and Jubileu, did not show any increase of seed oil content in the second year (Figure 5). The values of the controls obtained in our trial, especially in the first year, were lower than the average value for seed oil content in hemp $(25 \%-35 \%)$, as reported by several authors in other experiments [28-32]. The elevated maximum temperature above $30^{\circ} \mathrm{C}$, recorded constantly during the months of July and August, corresponding to the flowering-seed filling period, probably contributed to reducing the filling degree of the seeds, negatively affecting seed oil accumulation as demonstrated in other more studied species such as sunflowers [33-36]. This hypothesis would also explain the higher seed oil content of 2017, when the 
medium-late cultivars (Dora, Fibrol, Futura, and Monoica) underwent the seed maturation period from mid-August until September 20, when daily temperatures were much milder than before (Table 2).
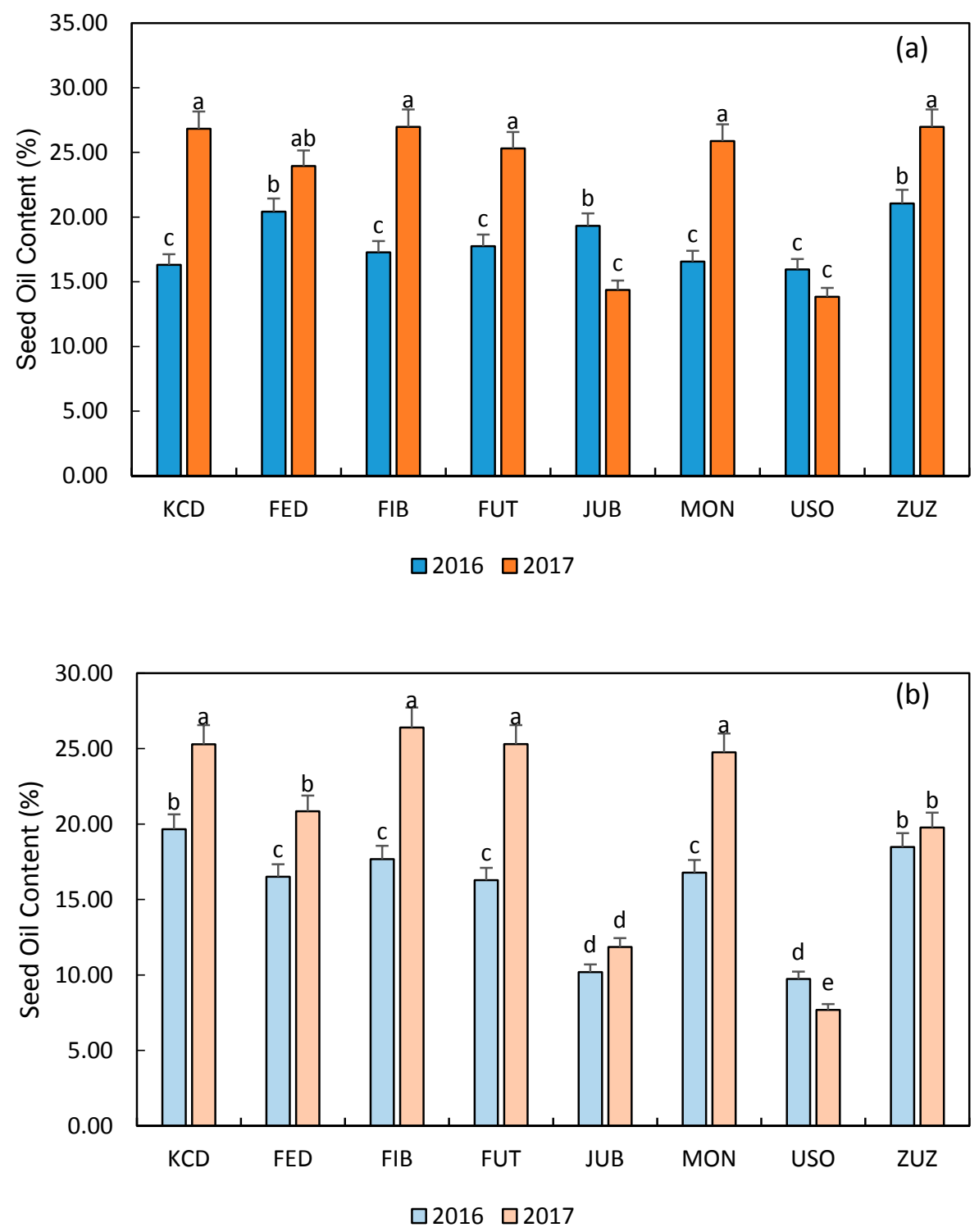

Figure 5. Seed oil content in control plants (a) and in plants with inflorescence harvested at flowering (b) $(\mathrm{KCD}=\mathrm{KC}$ Dora; FED = Fedora 17; FIB = Fibrol; FUT = Futura 75; JUB = Jubileu; MON = Monoica; USO = Uso-31; ZUZ = Zuzana). Means followed by the same letter are not significantly different (SNK at the 5\% level). Error bars are standard deviations.

With regard to the same characteristic in the plants with inflorescence removed, all cultivars had similarly reduced seed oil content in 2016 compared to 2017, with Uso-31 and Jubileu showing the lowest values when averaged over the two years ( 8.7 and $11 \%$, respectively).

\subsection{Biomass, Seed, and Oil Yield}

Stem, seed, and oil yield of the control plants were influenced by year $(\mathrm{Y})$ and cultivar $(\mathrm{C})$, but not by their interaction $(\mathrm{C} \times \mathrm{Y})$ (Table 3 ). Stem biomass yield, as a mean across cultivars, was the same in both years $\left(6.1 \mathrm{t} \mathrm{ha}^{-1}\right)$, despite the increased height of the stems recorded in 2016, which was compensated by a greater stem diameter in 2017. Among the cultivars, Futura, Monoica, and Dora exceeded the $7 \mathrm{t} \mathrm{ha}^{-1}$ dry matter of stem biomass $\left(8.3,7.8\right.$, and $7.7 \mathrm{t} \mathrm{ha}^{-1}$, respectively (Figure 6), 
considered relevant for European markets [5], and these cultivars, being monoecious, are suitable for a dual purpose. Regarding the seed yield of the controls, the first year on average across cultivars resulted in a statistically higher seed yield $\left(0.62 \mathrm{t} \mathrm{ha}^{-1}\right)$ than $2017\left(0.45 \mathrm{tha}^{-1}\right)$. In this case, the effect of high temperatures and low rainfall could be the cause of these differences in seed yield between the years. In fact, all cultivars started to flower between 16 July (Fedora and Zuzana) and 18 August 2017 , a period characterized by very high maximum temperatures $\left(+1.8^{\circ} \mathrm{C}\right.$ on average with respect to the previous 25 years) and low rainfall (Table 2). On the contrary, in 2016 cultivars started to flower at the end of July to 1 August, with slightly more favorable climatic conditions (Table 2, Figure 1). Exceptions were the earliest cultivars (Uso-31 and Jubileu), which started to flower at the end of June in both years.

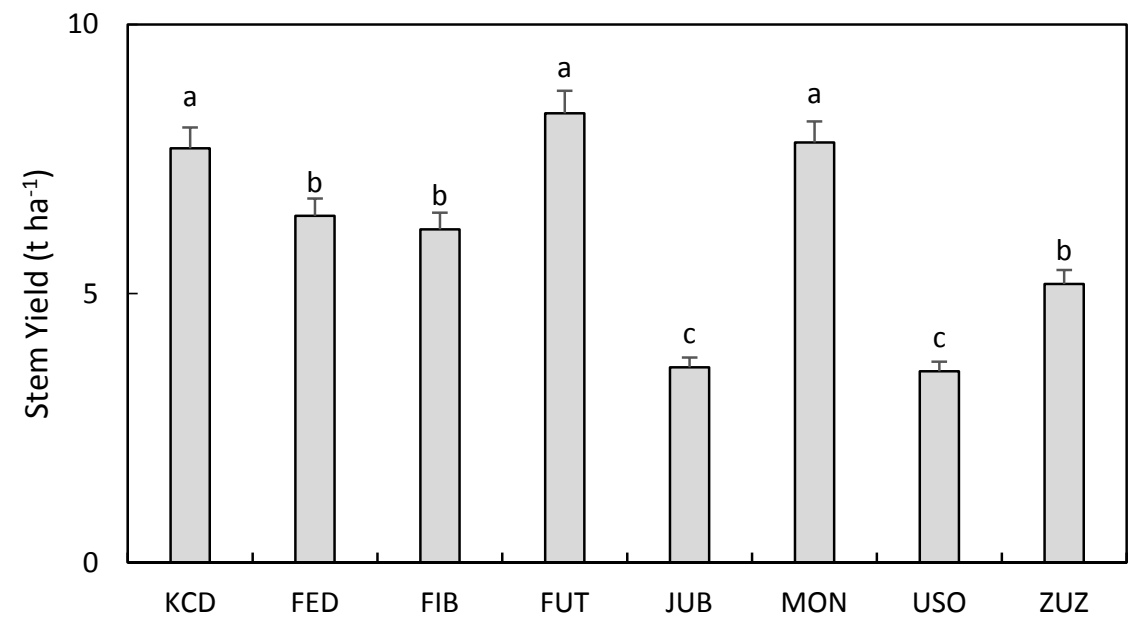

Figure 6. Stem yield at seed harvest of the hemp cultivars studied (KCD $=$ KC Dora; FED $=$ Fedora 17; FIB = Fibrol; FUT = Futura 75; JUB = Jubileu; MON = Monoica; USO = Uso-31; ZUZ = Zuzana). Means followed by the same letter are not significantly different (SNK at the 5\% level). Error bars are standard deviations.

It is well known that, as in other oil crops, high temperatures at the anthesis stage are detrimental for seed yield because they interfere with pollen production and floret fertility [37], affecting pollination phase and the first development of the embryo rather than the ending of the seed filling period. This hypothesis explains the lack of significant differences in 1000 seed weight recorded over the years. Among the cultivars, as a mean across the years, Fedora recorded the highest seed yield $\left(0.79 \mathrm{tha}^{-1}\right)$ (Figure 7), a value similar to that indicated by Desanlis et al. [38] as the average European yield $\left(1 \mathrm{tha}^{-1}\right)$. On the contrary, Fibrol showed the lowest value $\left(0.36 \mathrm{t} \mathrm{ha}^{-1}\right)$.

In all cultivars studied, the plants, once deprived of the inflorescence, reacted by emitting new shoots (2-4 per plant) which provided new seeds in both years. In particular, the seed yield of these plants, as a mean across cultivars, was almost double in $2016\left(0.45 \mathrm{t} \mathrm{ha}^{-1}\right)$ compared to the amount in $2017\left(0.25 \mathrm{t} \mathrm{ha}^{-1}\right)$, corresponding to 73 and $57 \%$ of seed production of the respective controls in the first and second year, respectively. Among the cultivars averaged over years, Fibrol produced the lowest seed yield $\left(0.23 \mathrm{t} \mathrm{ha}^{-1}\right)$ and Fedora $\left(0.51 \mathrm{t} \mathrm{ha}^{-1}\right)$ the highest, with Zuzana providing the best relative production compared to the control (about $82 \%$ ) (Table 4 ). 


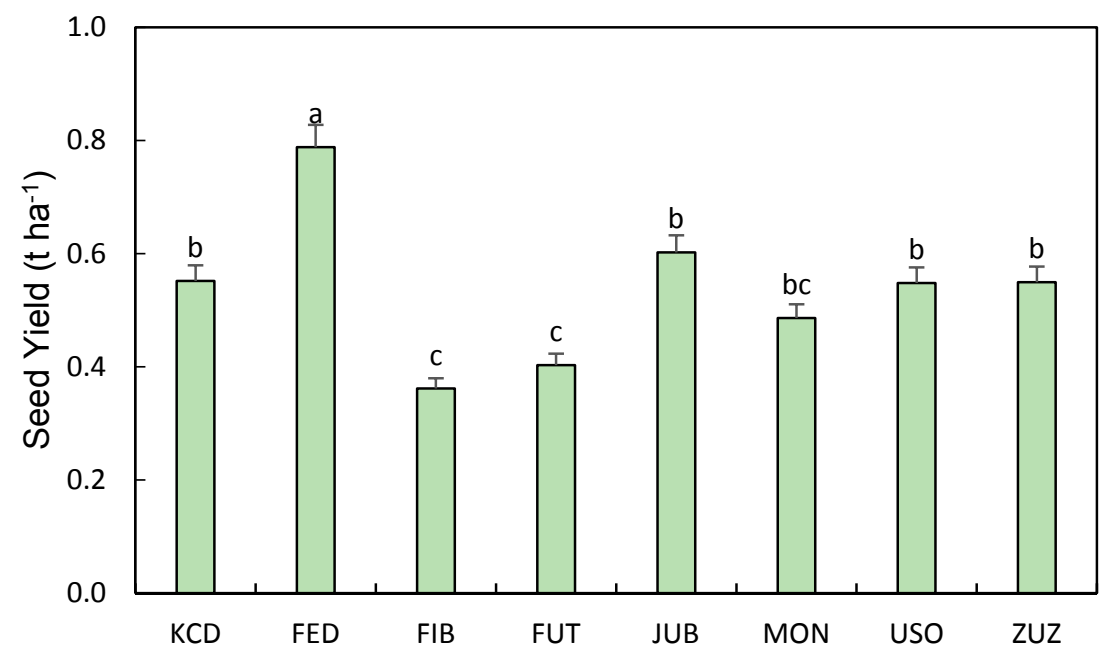

Figure 7. Seed yield of the control plants of cultivars studied $(\mathrm{KCD}=\mathrm{KC}$ Dora; FED = Fedora 17; FIB = Fibrol; FUT = Futura 75; JUB = Jubileu; MON = Monoica; USO = Uso-31; ZUZ = Zuzana). Means followed by the same letter are not significantly different (SNK at the $5 \%$ level). Error bars are standard deviations.

Table 4. Oil and seed yield of hemp cultivars studied (control) and of the same plants with inflorescence harvested at flowering. Results are means.

\begin{tabular}{ccccc}
\hline \multirow{2}{*}{ Cultivar } & \multicolumn{2}{c}{ Seed Yield (t ha ${ }^{-\mathbf{1}}$ ) } & \multicolumn{2}{c}{ Oil Yield (t ha $^{\mathbf{- 1}}$ ) } \\
\cline { 2 - 5 } & Control (Regular Plants) & With Inflorescence Harvested & Control (Regular Plants) & With Inflorescence Harvested \\
\hline Kc Dora & $0.55 \mathrm{~b}$ & $0.37 \mathrm{~b}$ & $0.12 \mathrm{~b}$ & $0.08 \mathrm{ab}$ \\
Fedora 17 & $0.79 \mathrm{a}$ & $0.51 \mathrm{a}$ & $0.17 \mathrm{a}$ & $0.09 \mathrm{a}$ \\
Fibrol & $0.36 \mathrm{e}$ & $0.23 \mathrm{e}$ & $0.07 \mathrm{~cd}$ & $0.05 \mathrm{c}$ \\
Futura 75 & $0.40 \mathrm{~d}$ & $0.30 \mathrm{c}$ & $0.09 \mathrm{c}$ & $0.06 \mathrm{c}$ \\
Jubileu & $0.60 \mathrm{~b}$ & $0.38 \mathrm{~b}$ & $0.10 \mathrm{c}$ & $0.04 \mathrm{~cd}$ \\
Monoica & $0.49 \mathrm{c}$ & $0.26 \mathrm{~d}$ & $0.09 \mathrm{c}$ & $0.05 \mathrm{c}$ \\
Uso-31 & $0.55 \mathrm{~b}$ & $0.37 \mathrm{~b}$ & $0.08 \mathrm{c}$ & $0.03 \mathrm{~d}$ \\
Kc Zuzana & $0.55 \mathrm{~b}$ & $0.46 \mathrm{a}$ & $0.13 \mathrm{~b}$ & $0.08 \mathrm{a}$ \\
\hline Average & 0.55 & 0.36 & 0.11 & 0.06 \\
\hline
\end{tabular}

Means within columns followed by different letters are significantly different using the SNK test $(p=0.05)$.

In the controls, oil yield was mainly affected by cultivars (Table 3 ). Among the cultivars, Fedora was significantly the most productive $\left(0.17 \mathrm{t} \mathrm{ha}^{-1}\right)$ and Fibrol the least $\left(0.07 \mathrm{t} \mathrm{ha}^{-1}\right)$ (Table 4$)$.

In plants with inflorescence removed, year and cultivar had the same effect (Table 5). In this case, oil yield was 0.07 and $0.05 \mathrm{tha}^{-1}$ in 2016 and 2017, respectively, corresponding to 63 and $48 \%$ of the check controls, respectively; among the cultivars, Fedora obtained the highest oil yield $\left(0.09 \mathrm{t} \mathrm{ha}^{-1}\right)$, though it was not significantly different from the yields obtained by Dora $\left(0.08 \mathrm{tha}^{-1}\right)$ and Zuzana $\left(0.08 \mathrm{tha}^{-1}\right)$ (Table 4$)$.

Table 5. Statistical significance (ANOVA) of year and cultivar effects on some traits in plants with inflorescence removed.

\begin{tabular}{ccccc}
\hline Source & Seed Yield & Oil Content & 1000 Seed Weight & Oil Yield \\
\hline Year $(\mathrm{Y})$ & $* * *$ & $* * *$ & $* * *$ & $* *$ \\
Cultivar $(\mathrm{C})$ & $* * *$ & $* * *$ & $* * *$ & $* *$ \\
$\mathrm{C} \times \mathrm{Y}$ & $\mathrm{ns}$ & $\mathrm{ns}$ & $* *$ & $\mathrm{~ns}$ \\
\hline
\end{tabular}

$*, * *, \overline{\text { and }}{ }^{* * *}$ indicate significance at the $p<0.05,0.01$, and 0.001 levels, respectively. ns $=$ not significant. 


\subsection{Oil Fatty Acids Composition}

Oil quality was monitored in the controls during 2016 only. The average content of saturated fatty acids (palmitic and stearic acid) was $10.3 \%$, monounsaturated fatty acids (oleic acid) corresponded to $15.0 \%$, and the content of polyunsaturated fats (linoleic acid, $\alpha$-linolenic, and $\gamma$-linolenic) was $74.0 \%$ (Table 6). The average $\omega$-3) / $\omega$-6 ratio ( $\alpha$-linolenic plus $\gamma$-linolenic/linoleic acid) was 0.32 , in agreement with the results obtained by Galasso et al. [39] and confirmed as an optimal proportion for human metabolism and health according to recent medical recommendations $[30,40]$. Among the cultivars, Fibrol and Monoica showed the lowest ratio (0.30), Jubileu and Dora the highest (0.34). As regards the differences in saturated fatty acids content among the cultivars, the palmitic acid concentration ranged from $8.1 \%$ in Fibrol to $6.2 \%$ in Uso-31, while the stearic acid content ranged from $3.1 \%$ in Dora to $2.5 \%$ in Monoica (Table 6). All of these values are consistent with those found by other authors $[29,30,40,41]$. The cultivar with the maximum oleic acid content was Fibrol (16.7\%), while Dora showed the lowest (13.7\%) (Table 6), in agreement with the 10-16\% range found by Deferne and Pate [30] and Calloway and Laakkonen [40]. However, the oleic acid levels results obtained here are slightly higher than the levels found by Vonapartis et al. [29] (9.5-13\%). Referring to the polyunsaturated fatty acids, the average linoleic acid content was $56 \%$, ranging from $56.7 \%$ in Monoica to $55.1 \%$ in Fibrol. The highest $\alpha$-linolenic acid content was in Dora (17.7\%), the lowest in Fibrol (15.5\%), with an experimental average of $16.3 \%$. The mean $\gamma$-linolenic acid concentration was $1.6 \%$, ranging from $2.4 \%$ in Jubileu to $0.9 \%$ in Monoica (Table 6). These results were comparable to the values reported by several authors $[29,30,40,41]$. The acidic profile of the oil is influenced not only by the cultivar factor, but also by climatic conditions during the oil accumulation period [42]. As occurs in other oil crops such as sunflowers, the relative oleic/linoleic content ratio is strongly affected by temperatures during seed development and different oil qualities are obtained from the same cultivar in different environments. In particular, this could be attributed to a significant inhibition of $\Delta-12$ desaturase activity, responsible for the desaturation from oleic acid (18:1) to linoleic acid (18:2) caused by high temperature $\left(>30^{\circ} \mathrm{C}\right)[43]$.

Table 6. Oil fatty acid composition of hemp cultivars studied. Results are means \pm SE. $\omega 3 / \omega 6$ ratio is dimensionless.

\begin{tabular}{cccccccc}
\hline \multirow{2}{*}{ Cultivar } & \multicolumn{7}{c}{ Fatty Acid (\%) } \\
\cline { 2 - 7 } & Palmitic & Stearic & Oleic & Linoleic & $\alpha$-Linolenic & $\gamma$-Linolenic & Others \\
\hline Fedora 17 & $7.8 \pm 0.35$ & $2.9 \pm 0.18$ & $14.1 \pm 0.67$ & $56.3 \pm 0.39$ & $15.7 \pm 0.11$ & $2.2 \pm 0.02$ & $0.7 \pm 0.40$ \\
Fibrol & $8.1 \pm 0.13$ & $2.8 \pm 0.01$ & $16.7 \pm 0.27$ & $55.1 \pm 0.14$ & $15.5 \pm 0.25$ & $1.2 \pm 0.22$ & $0.5 \pm 0.01$ \\
Futura 75 & $7.5 \pm 0.31$ & $2.9 \pm 0.10$ & $15.0 \pm 0.19$ & $56.2 \pm 0.20$ & $16.0 \pm 0.69$ & $1.4 \pm 0.01$ & $0.9 \pm 0.46$ \\
Jubileu & $7.2 \pm 0.54$ & $3.0 \pm 0.08$ & $14.4 \pm 0.45$ & $55.6 \pm 0.40$ & $16.6 \pm 0.11$ & $2.4 \pm 0.10$ & $0.8 \pm 0.08$ \\
KC Dora & $7.6 \pm 0.49$ & $3.1 \pm 0.07$ & $13.7 \pm 0.11$ & $56.0 \pm 0.90$ & $17.7 \pm 0.24$ & $1.2 \pm 0.05$ & $0.7 \pm 0.16$ \\
Monoica & $7.3 \pm 0.67$ & $2.5 \pm 0.08$ & $16.2 \pm 0.61$ & $56.7 \pm 0.62$ & $16.1 \pm 0.63$ & $0.9 \pm 0.34$ & $0.4 \pm 0.06$ \\
Uso-31 & $6.9 \pm 0.17$ & $2.8 \pm 0.09$ & $14.9 \pm 1.02$ & $56.1 \pm 0.40$ & $16.2 \pm 0.58$ & $2.3 \pm 0.11$ & $0.8 \pm 0.04$ \\
KC Zuzana & $7.0 \pm 0.00$ & $2.8 \pm 0.00$ & $15.1 \pm 0.00$ & $55.9 \pm 0.00$ & $16.8 \pm 0.00$ & $1.6 \pm 0.00$ & $0.9 \pm 0.00$ \\
Average & $7.4 \pm 0.30$ & $2.9 \pm 0.12$ & $15.0 \pm 0.41$ & $56.0 \pm 0.39$ & $16.3 \pm 0.29$ & $1.7 \pm 0.14$ & $0.7 \pm 0.14$ \\
\hline
\end{tabular}

\subsection{Essential Oil (EO)}

The cultivar $\times$ year interaction affected the inflorescence (as tons of dry matter per hectare) and essential oil (as liter per hectare) yield significantly. Conversely, the EO concentration in the inflorescence (as percentage on dry matter) was affected by cultivar (Table 7). 
Table 7. Statistical significance (ANOVA) of year, cultivar, and their interaction on inflorescence yield, essential oil concentration in the inflorescences (EO concentration), and essential oil yield (EO yield).

\begin{tabular}{cccc}
\hline Source & Inflorescence Yield & EO Concentration & EO Yield \\
\hline Year $(\mathrm{Y})$ & $*$ & $\mathrm{~ns}$ & $*$ \\
Cultivar $(\mathrm{C})$ & $* * *$ & $* *$ & $* *$ \\
$\mathrm{C} \times \mathrm{Y}$ & $*$ & $\mathrm{~ns}$ & $* *$ \\
\hline$* * *$, and $^{* * *}$ indicate significance at the $p<0.05,0.01$ and 0.001 levels, respectively. $\mathrm{ns}=$ not significant.
\end{tabular}

The EO concentration, as a mean across years, ranged from the value of $0.2 \%$, the minimum obtained in Dora, to $0.3 \%$, the maximum obtained in Futura. Both inflorescence and essential oil yield, as means across cultivars, were higher in $2017\left(1.91 \mathrm{tha}^{-1}\right.$ and $4.80 \mathrm{~L} \mathrm{ha}^{-1}$, respectively) than in 2016 (1.57 t ha ${ }^{-1}$ and $3.96 \mathrm{~L} \mathrm{ha}^{-1}$, respectively). The inflorescence yield remained constant or registered a slight increase in all cultivars in 2017 compared to 2016, with the exception of Uso-31, which a had significantly reduced performance $(-38 \%)$, and Futura, which had a significantly increased yield $(+88 \%)$ in the second year (Figure 8$)$. Similarly, regarding the EO yield, the values ranged between $2.0 \mathrm{~L} \mathrm{ha}^{-1}$ (Zuzana in 2016) and $11.8 \mathrm{~L} \mathrm{ha}^{-1}$ (Futura in 2017), with significantly increased production in Futura in 2017 compared to 2016 (Figure 8). Inflorescences yield at full flowering was very similar to the production previously obtained in Italy $\left(2.4 \mathrm{t} \mathrm{ha}^{-1}\right)$ in 2013 by Tang et al. [4] and slightly lower than that obtained by Nissen et al. [12] in 2005 (about $4 \mathrm{t} \mathrm{ha}^{-1}$ ) (Figure 8). The average EO concentration obtained in this experiment was similar to the results obtained by Bertoli et al. [9] and Verma et al. [44]. The essential oil yield obtained in this experiment was comparable to amounts reported by Meier and Mediavilla [45] in a trial carried out in Switzerland utilizing a set of cultivars which included, among others, Fedora and Futura (range of about 4.5-11 L ha ${ }^{-1}$ ). The same authors showed that the EO yield was affected by cultivar, harvest time, and plant density. In addition, the prevention of pollination could lead to greater amounts of flowers and to a significantly higher essential oil yield, but this practice in fields with an economically relevant size is almost impossible. Moreover, the above aspects with the different growing pedo-climatic conditions (mainly temperature and rainfall) can influence the composition of hemp EO $[9,12,44,45]$, which will be addressed in a future study.

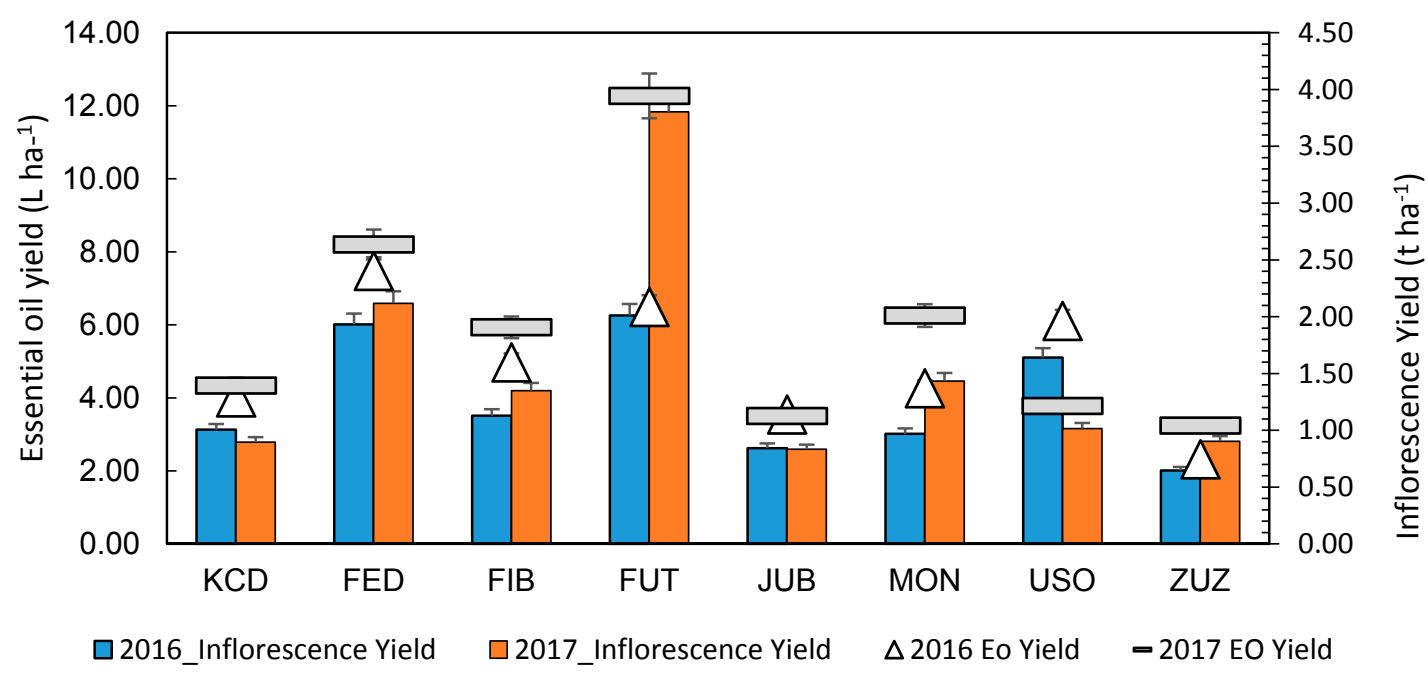

Figure 8. Inflorescence yield and EO yield of the hemp cultivars studied. Data are means, error bars are standard deviations. $(\mathrm{KCD}=\mathrm{KC}$ Dora; FED = Fedora 17; FIB = Fibrol; FUT = Futura 75; JUB = Jubileu; $\mathrm{MON}=$ Monoica; USO = Uso-31; ZUZ = Zuzana). 


\section{Conclusions}

The trial environment showed a potential for biomass yield similar or higher to that which is considered the European goal, although only monoecious cultivars were used. On the contrary, the potential for seed production was lower than expected, due to the climatic conditions during the flower-grain filling period of both experiments and the scarce water retention capacity of the soil. During the same hemp phenological phase in 2016, similar maximum temperatures and rainfall with respect to the average of previous 25 -year period were recorded. The year 2017 instead showed higher temperatures and lower rainfall than historical records. Futura, however, produced the highest inflorescences and essential oils yield as well as the highest stem yield at seed maturity. Fedora was the most suitable cultivar for food purposes, producing both the highest seed and oil yield. All of the cultivars, once deprived of the main inflorescence, reacted by issuing new inflorescences able to provide about $67 \%$ of seed yield with respect to the controls (intact plants). Even with the main inflorescence removal, Fedora stood out as the most productive cultivar for seed and oil yield, when the plant inflorescences were harvested at flowering time. More attention should be focused on breeding, as some monoecious cultivars (all of Hungarian origin) had an excessive number of full-male plants, probably due to an inadequate and insufficient selection and stability of the basic genetic material utilized for field seed reproduction. The qualitative characteristics of hemp oil were not affected by cultivar. In conclusion, although the hemp grower should always be clear about the main production objective, we can affirm that the monoecious hemp cultivars available today allow a multipurpose exploitation of the crop. In fact, the same crop could supply inflorescences (essential oil, phytocannabinoids, etc.), seeds (vegetable oil and meal), and stems (industrial application), improving crop sustainability. This could encourage the completion of the supply chain at a local level, including investments in first-processing technologies.

Author Contributions: G.D. and F.Z. performed the experiments, carried out the field measurements, and analyzed the data; B.P. and A.S. carried out distillation, GC/FID, and GC/MS analysis. F.D. and C.C. helped with valuable comments on the manuscript; M.B. and C.F. conceived and designed the experiments and wrote the paper.

Acknowledgments: This experimentation was possible thanks to the contribution and technical support of the Regional Agency for Rural Development (ERSA) of the Friuli Venezia Giulia region. The authors would like to thank Andrea Fabris for the laboratory analysis on seeds.

Conflicts of Interest: The authors declare that there are no conflicts of interest regarding the publication of this paper.

\section{References}

1. Allegret, S. The Hystory of Hemp. In Hemp: Industrial Production and Uses Hemp; Bouloc, P., Allegret, S., Arnaud, L., Eds.; CAB international: Bar sur Aube, France, 2013; pp. 4-25. ISBN 9781845937928.

2. Salentijn, E.M.J.; Zhang, Q.; Amaducci, S.; Yang, M.; Trindade, L.M. New developments in fiber hemp (Cannabis sativa L.) breeding. Ind. Crops Prod. 2015, 68, 32-41. [CrossRef]

3. Amaducci, S.; Scordia, D.; Liu, F.H.; Zhang, Q.; Guo, H.; Testa, G.; Cosentino, S.L. Key cultivation techniques for hemp in Europe and China. Ind. Crops Prod. 2015, 68, 2-16. [CrossRef]

4. Tang, K.; Struik, P.; Yin, C.X.; Thouminot, C.; Bjelková, M.; Stramkale, V.; Amaducci, S. Comparing hemp (Cannabis sativa L.) cultivars for dual-purpose production under contrasting environments. Ind. Crops Prod. 2016, 87, 33-44. [CrossRef]

5. Carus, M.; Karst, S.; Kauffmann, A.; Hobson, J.; Bertucelli, S. The European Hemp Industry: Cultivation, Processing and Applications for Fibres, Shives and Seeds. European Hemp Industry Association, 2013. Available online: http://eiha.org/media/2014/10/13--06-European-Hemp-Industry.pdf (accessed on 5 June 2017).

6. European Industrial Hemp Association. Hemp Cultivation Area in Europe. 2016. Available online: http: / / eiha.org/media/2017/03/17-02-Hemp-Cultivation-Area-Europe.png (accessed on 5 June 2017).

7. Mihoc, M.; Pop, G.; Alexa, E.; Radulov, I. Nutritive quality of Romanian hemp varieties (Cannabis sativa L.) with special focus on oil and metal contents of seeds. Chem. Cent. J. 2012, 6, 122. [CrossRef] [PubMed] 
8. Mandolino, G.; Carboni, A.; Bagatta, M.; Moliterni, V.M.C.; Ranalli, P. Occurrence and frequency of putatively Y chromosome linked DNA markers in Cannabis sativa L. Euphytica 2002, 126, 211-218. [CrossRef]

9. Bertoli, A.; Tozzi, S.; Pistelli, L.; Angelini, L.G. Fibre hemp inflorescences: From crop-residues to essential oil production. Ind. Crops Prod. 2010, 32, 329-337. [CrossRef]

10. Hazekamp, A.; Fischedick, J.T. Cannabis-From cultivar to chemovar. Drug Test. Anal. 2012, 4, 660-667. [CrossRef] [PubMed]

11. Appendino, G.; Gibbons, S.; Giana, A.; Pagani, A.; Grassi, G.; Stavri, M.; Smith, E.; Rahman, M.M. Antibacterial cannabinoids from Cannabis sativa: A structure-activity study. J. Nat. Prod. 2008, 71, 1427-1430. [CrossRef] [PubMed]

12. Nissen, L.; Zatta, A.; Stefanin, I.; Grandi, S.; Sgorbati, B.; Biavati, B.; Monti, A. Characterization and antimicrobial activity of essential oils of industrial hemp varieties (Cannabis sativa L.). Fitoterapia 2010, 81, 413-419. [CrossRef] [PubMed]

13. Mukhtar, T.; Kayani, M.Z.; Hussain, M.A. Nematicidal activities of Cannabis sativa L. and Zanthoxylum alatum Roxb. against Meloidogyne incognita. Ind. Crops Prod. 2013, 42, 447-453. [CrossRef]

14. Grewal, P.S. Effects of leaf-matter incorporation on Aphelenchoides composticola (Nematoda), mycofloral composition, mushroom compost quality and yield of Agaricus bisporus. Ann. Appl. Biol. 1989, 115, $299-312$. [CrossRef]

15. Zia, A.; Aslam, M.; Naz, F.; Illyas, M. Bio-efficacy of some plant extracts against chickpea beetle, Callosobruchus chinensis Linnaeus (Coleoptera: Bruchidae) attacking chickpea. Pak. J. Zool. 2011, 43, 733-737.

16. Górski, R.; Szklarz, M.; Kaniewski, R. Efficacy of hemp essential oil in the control of rosy apple aphid (Dysaphis plantaginea Pass.) occurring on apple tree. Prog. Plant Prot. 2009, 49, 2013-2016.

17. Bedini, S.; Flamini, G.; Cosci, F.; Ascrizzi, R.; Benelli, G.; Conti, B. Cannabis sativa and Humulus lupulus essential oils as novel control tools against the invasive mosquito Aedes albopictus and fresh water snail Physella acuta. Ind. Crops Prod. 2016, 85, 318-323. [CrossRef]

18. Benelli, G.; Pavela, R.; Lupidi, G.; Nabissi, M.; Petrelli, R.; Ngahang Kamte, S.L.; Cappellacci, L.; Fiorini, D.; Sut, S.; Dall'Acqua, S.; et al. The crop-residue of fiber hemp cv. Futura 75: From a waste product to a source of botanical insecticides. Environ. Sci. Pollut. Res. 2017. [CrossRef] [PubMed]

19. Amaducci, S.; Zatta, A.; Pelatti, F.; Venturi, G. Influence of agronomic factors on yield and quality of hemp (Cannabis sativa L.) fibre and implication for an innovative production system. Field Crops Res. 2008, 107, 161-169. [CrossRef]

20. Mediavilla, V.; Jonquera, M.; Schmid-Slembrouck, I.; Soldati, A. Decimal code for growth stages of hemp (Cannabis sativa L.). J. Int. Hemp Assoc. 1998, 5, 68-74.

21. Amaducci, S.; Colauzzi, M.; Bellocchi, G.; Venturi, G. Modelling post-emergent hemp phenology (Cannabis sativa L.): Theory and evaluation. Eur. J. Agron. 2008, 28, 90-102. [CrossRef]

22. Bócsa, I.; Karus, M. The Cultivation of Hemp: Botany, Varieties, Cultivation and Harvesting; Hemptech: Sebastopol, CA, USA, 1998; p. 184. ISBN 978-1886874039.

23. Heslop-Harrison, J.; Heslop-Harrison, Y. Cannabis sativa L. In The Induction of Flowering; Evans, L.T., Ed.; Macmillan: Canberra, Australia, 1969; pp. 205-226.

24. De Meijer, E.P.M.; Keizer, L.C.P. Patterns of diversity in Cannabis. Genet. Resour. Crop Evol. 1996, 43, 41-52. [CrossRef]

25. Cosentino, S.L.; Testa, G.; Scordia, D.; Copani, V. Sowing time and prediction of flowering of different hemp (Cannabis sativa L.) genotypes in southern Europe. Ind. Crops Prod. 2012, 37, 20-33. [CrossRef]

26. Faux, A.M.; Draye, X.; Lambert, R.; d'Andrimont, R.; Raulier, P.; Bertin, P. The relationship of stem and seed yields to flowering phenology and sex expression in monoecious hemp (Cannabis sativa L.). Eur. J. Agron. 2013, 47, 11-22. [CrossRef]

27. Cromack, H.T.H. The effect of cultivar and seed density on the production and fibre content of Cannabis sativa L. in southern England. Ind. Crops Prod. 1998, 7, 205-210. [CrossRef]

28. House, J.D.; Neufeld, J.; Leson, G. Evaluating the quality of protein from hemp seed (Cannabis sativa L.) products through the use of the protein digestibility-corrected amino acid score method. J. Agric. Food Chem. 2010, 58, 11801-11807. [CrossRef] [PubMed]

29. Vonapartis, E.; Aubin, M.P.; Seguin, P.; Mustafa, A.F.; Charron, J.B. Seed composition of ten industrial hemp cultivars approved for production in Canada. J. Food Compos. Anal. 2015, 39, 8-12. [CrossRef]

30. Deferne, J.L.; Pate, D.W. Hemp seed oil: A source of valuable essential fatty acids. J. Int. Hemp Assoc. 1996, 3, 4-7. 
31. Pate, D.W. Hemp seed: A valuable food source. In Advances in Hemp Research, Ranalli, P., Ed.; The Haworth Press: NY, USA, 1999; pp. 243-255.

32. Johnson, P. Industrial hemp: A critical review of claimed potentials for Cannabis sativa. Tappi J. 1999, 82, 113-123.

33. Rondanini, D.; Mantese, A.; Savin, R.; Hall, A.J. Responses of sunflower yield and grain quality to alternating day/night high temperature regimes during grain filling: Effects of timing, duration and intensity of exposure to stress. Field Crops Res. 2006, 96, 48-62. [CrossRef]

34. Rondanini, D.; Savin, R.; Hall, A.J. Dynamics of fruit growth and oil quality of sunflower (Helianthus annuus L.) exposed to brief intervals of high temperature during grain filling. Field Crops Res. 2003, 83, 79-90. [CrossRef]

35. Connor, D.J.; Hall, A.J. Sunflower physiology. In Sunflower Technology and Production; Schneiter, A.A., Ed.; ASA, SCSA and SSSA: Madison, WI, USA, 1997; pp. 113-182.

36. Harris, H.C.; McWilliam, J.R.; Mason, W.K. Influence of temperature on oil content and composition of sunflower seed. Aust. J. Agric. Res. 1978, 29, 1203-1212. [CrossRef]

37. Chimenti, C.A.; Hall, A.J. Grain number responses to temperature during floret differentiation in sunflower. Field Crops Res. 2001, 72, 177-184. [CrossRef]

38. Desanlis, F.; Cerruti, N.; Warner, P. Hemp agronomics and cultivation. In Hemp: Industrial Production and Uses Hemp; Bouloc, P., Allegret, S., Arnaud, L., Eds.; CAB international: Bar sur Aube, France, 2013; pp. 98-124. ISBN 9781845937928.

39. Galasso, I.; Russo, R.; Mapelli, S.; Ponzoni, E.; Brambilla, I.M.; Battelli, G.; Reggiani, R. Variability in seed traits in a collection of Cannabis sativa L. genotypes. Front. Plant Sci. 2016, 7, 688. [CrossRef] [PubMed]

40. Calloway, J.C.; Laakkonen, T.T. Cultivation of Cannabis oil seed varieties in Finland. J. Int. Hemp Assoc. 1996, 3, 32-34.

41. Da Porto, C.; Decorti, D.; Tubaro, F. Fatty acid composition and oxidation stability of hemp (Cannabis sativa L.) seed oil extracted by supercritical carbon dioxide. Ind. Crops Prod. 2012, 36, 401-404. [CrossRef]

42. Leizer, C.; Ribnicky, D.; Poulev, A.; Dushenkov, S.; Raskin, I. The composition of hemp seed oil and its potential as an important source of nutrition. J. Nutraceuticals Funct. Med. Foods 2000, 2, 35-53. [CrossRef]

43. Garces, R.; Mancha, M. In vitro oleate desaturate in developing sunflower seed. Phytochemistry 1991, 30, 2127-2130. [CrossRef]

44. Verma, R.S.; Padalia, R.C.; Verma, S.K.; Chauhan, A.; Darokar, M.P. The essential oil of 'bhang' (Cannabis sativa L.) for non-narcotic applications. Curr. Sci. 2014, 107, 645-650.

45. Meier, C.; Mediavilla, V. Factors influencing the yield and the quality of hemp (Cannabis sativa L.) essential oil. J. Int. Hemp Assoc. 1998, 5, 16-20. 